\title{
Neonatal outcomes of preterm or very-low- birth-weight infants over a decade from Queen Mary Hospital, Hong Kong: comparison with the Vermont Oxford Network
}

\author{
YY Chee *, Mabel SC Wong, Rosanna MS Wong, KY Wong
}

\section{A B S T R A C T}

Introduction: There is a paucity of local data on neonatal outcomes of preterm/very-low-birthweight infants in Hong Kong. This study aimed to evaluate the survival rate on discharge and morbidity of preterm/very-low-birth-weight infants $(\leq 29+6$ weeks and/or birth weight $<1500 \mathrm{~g}$ ) over a decade at Queen Mary Hospital in Hong Kong, so as to provide centre-specific data for prenatal counselling and to benchmark these results against the Vermont Oxford Network.

Methods: Standardised perinatal/neonatal data were collected for infants with gestational age of $23+0$ to $29+6$ weeks and/or birth weight of $<1500 \mathrm{~g}$ who were born at Queen Mary Hospital between 1 January 2005 and 31 December 2014. These data were compared with all neonatal centres in the Vermont Oxford Network in 2013. The Chi squared test was used to compare the categorical Queen Mary Hospital data with that of Vermont Oxford Network. A two-tailed P value of $<0.05$ was considered statistically significant.

Results: The overall survival rate on discharge from Queen Mary Hospital for 449 infants was significantly higher than that of the Vermont Oxford Network (87\% versus $80 \% ; \mathrm{P}=0.0006)$. The morbidity-free survival at Queen Mary Hospital (40\%) was comparable with the Vermont Oxford Network (44\%). At Queen Mary Hospital, $86 \%$ of infants had respiratory distress syndrome, $40 \%$ bronchopulmonary dysplasia, $44 \%$ haemorrhage, $5 \%$ necrotising enterocolitis, $10 \%$ severe retinopathy of prematurity, $10 \%$ late-onset sepsis, and $84 \%$ growth failure on discharge. Rates of respiratory distress syndrome, intraventricular haemorrhage, necrotising enterocolitis, and severe retinopathy of prematurity were similar in the two populations. At Queen Mary Hospital, significantly more infants had bronchopulmonary dysplasia $(\mathrm{P}=0.011)$, patent ductus arteriosus $(\mathrm{P}=0.015)$, and growth failure $(\mathrm{P}=0.0001)$ compared with the Vermont Oxford Network. In contrast, rate of late-onset sepsis was significantly lower at Queen Mary Hospital than the Vermont Oxford Network ( $\mathrm{P}=0.0002)$.

Conclusions: Mortality rate and most of the morbidity rates of our centre compare favourably with international standards, but rates of bronchopulmonary dysplasia and growth failure are of concern. A regular benchmarking process is crucial to audit any change in clinical outcomes after implementation of a local quality improvement project.

\section{Hong Kong Med J 2017;23:381-6 \\ DOI: 10.12809/hkmj166064 \\ YY Chee *, FHKAM (Paediatrics) \\ MSC Wong, FHKAM (Paediatrics), FHKCPaed \\ RMS Wong, FHKAM (Paediatrics) \\ KY Wong, FHKAM (Paediatrics)}

Department of Paediatrics and Adolescent Medicine, Queen Mary Hospital, Pokfulam, Hong Kong

* Corresponding author: yychee@hotmail.com

New knowledge added by this study

Mortality rate and most of the morbidity rates at our centre compare favourably with international standards.

- Significantly more preterm/very-low-birth-weight infants had bronchopulmonary dysplasia and growth failure at our centre compared with the Vermont Oxford Network. Identification of these areas for improvement could facilitate the development of a quality improvement project.

Implications for clinical practice or policy

- Local survival and morbidity rates provided by this study can be used for prenatal counselling about preterm delivery.

- The baseline data (growth failure rate upon discharge) obtained in the present study can be used to audit a future quality improvement project in the local community (standardised nutritional pathway for very-lowbirth-weight infants).

\section{Introduction}

There has been a substantial improvement in the outcomes for preterm infants over the past few decades. This improvement reflects the advances made in antenatal, perinatal, and neonatal care. It is crucial to audit and benchmark local data on clinical outcomes with international standards. ${ }^{1}$ One of the largest neonatal databases, the Vermont Oxford 


\section{香港瑪麗醫院十年期間的早產兒或非常低出生體 重嬰兒的新生兒結果：與佛蒙特牛津網絡的比較} 池月兒、黃小珍、黃明沁、黃嘉賢

引言：本地只有很少有關早產兒或非常低出生體重嬰兒的新生兒結 果數據。本研究旨在評估香港瑪麗醫院十年內的早產兒或非常低出 生體重嬰兒（即 $\leq 29+6$ 周和/或出生體重 $<1500$ 克）出院時的存活 率和發病率, 並將這些結果按佛蒙特牛津網絡（Vermont Oxford Network；VON）的數據指標衡量並作比較, 從而為本院的產前諮詢 服務提供資料。

方法：本研究收集2005年1月 1 日至2014年12月31日期間, 在瑪麗醫 院出生胎齡為 $23+0$ 至 $29+6$ 的嬰兒和/或出生體重 $<1500$ 克的新生兒數 據。所得數據與2013年VON所有新生兒進行比較。使用卡方檢驗來 比較兩組數據。雙尾P值少於 0.05 被認為具有統計學意義。

結果 : 研究期間瑪麗醫院的 449 名早產兒或非常低出生體重嬰兒的總 存活率為 $87 \%$, 明顯高於VON $(80 \%)$ [P=0.0006]。瑪麗醫院的無發 病存活率 $(40 \%)$ 與VON $(44 \%)$ 相若。瑪麗醫院的數據顯示 $86 \%$ 的 嬰兒出現呼吸窘迫綜合徵、 $40 \%$ 支氣管肺發育不良、 $44 \%$ 動脈導管未 閉、 $7 \%$ 嚴重腦室內出血、5\%壞死性小腸結腸炎、 $10 \%$ 重度早產兒視 網膜病變、 $10 \%$ 晚期膿毒症和 $84 \%$ 出院時生長遲緩。瑪麗醫院和VON 兩組數據在以下幾方面相若：呼吸窘迫綜合徵、嚴重腦室內出血、 壞死性小腸結腸炎和重度早產兒視網膜病變。與VON比較, 瑪麗醫 院明顯較多嬰兒有支氣管肺發育不良 $(\mathrm{P}=0.011)$ 、動脈導管未閉 $(\mathrm{P}=0.015)$ 和出院時生長遲緩 $(\mathrm{P}=0.0001)$ 。相反, 瑪麗醫院的晚 期膿毒症發病率明顯較低（ $\mathrm{P}=0.0002 ） 。$

結論：本院的早產兒或非常低出生體重嬰兒的死亡率和發病率與國際 標準相若，但支氣管肺發育不良和出院時生長遲緩的比率值得關注。 在本地實行質量改善計劃後, 定期進行基準測試來審核臨床結果的變 化至為重要

\section{Methods}

\section{Study population and clinical outcomes}

The study was conducted at QMH, Hong Kong, which is a tertiary referral perinatal centre with an annual delivery rate of approximately 3500 to 4500 . The hospital provides care for preterm infants who are predominantly of Chinese ethnicity. This study was done in accordance with the principles outlined in the Declaration of Helsinki.

Perinatal/neonatal data of all infants born alive at QMH with GA of $23+0$ to $29+6$ weeks and/ or birth weight of $<1500 \mathrm{~g}$ between 1 January 2005 and 31 December 2014 were collected. These infants were part of the VON database. Infants born outside of $\mathrm{QMH}$ were not included in this study. Data were collected retrospectively from the Clinical Management System and Clinical Information System and entered into the VON database by members of the QMH neonatal team.

Definitions for maternal and infant characteristics were provided in the manual "Nightingale Data Definitions" by the VON. In this study, GA was determined as the best obstetric estimate using ultrasonography and/or date of the last menstrual period. If no antenatal data were available, GA was estimated by postnatal neonatal assessment. Intrauterine growth restriction, defined as birth weight of $<10$ th percentile for gender and GA, was determined using growth charts published by Fenton and Kim. ${ }^{4}$ Maternal obstetric data included data on antenatal steroid use, presence of chorioamnionitis, and mode of delivery. Antenatal steroid therapy was considered to be given if it was provided to the mother during pregnancy at any time prior to delivery. Chorioamnionitis was diagnosed on histopathological findings.

The survival rate was defined as neonates who survived to the time of discharge. Surfactant was used as early rescue therapy for infants with respiratory distress syndrome (RDS), defined by the presence of clinical and radiological features within the first 24 hours of life. Conventional mechanical ventilation use at any time was defined as intermittent positive pressure ventilation through an endotracheal tube with a conventional ventilator at any time after leaving the delivery room. Rescue postnatal steroids were used beyond 2 weeks of age at our centre to facilitate extubation of ventilatordependent neonates with oxygen requirement of $>40 \%$ and significant radiological features of persistent lung disease. Data on infants discharged with oxygen were also collected.

Early-onset sepsis was defined as blood or cerebrospinal fluid culture-positive bacterial sepsis occurring within 72 hours of life. Haemodynamically significant patent ductus arteriosus (PDA) on twodimensional echocardiography was treated with 
intravenous ibuprofen (only data from 2010 to 2014 were collected as ibuprofen was used as medical treatment for PDA at QMH since 2010) or surgical ligation if medical treatment was unsuccessful or contra-indicated. Severe retinopathy of prematurity was defined as stage III or above according to international classification. ${ }^{5}$

The major morbidities included severe neurological injury (defined as grade 3 or 4 intraventricular haemorrhage [IVH], or periventricular leukomalacia [PVL]), bronchopulmonary dysplasia (BPD; defined as supplemental oxygen use at a postmenstrual age [PMA] of 36 weeks), pneumothorax (defined as extrapleural air diagnosed by chest radiograph or needle aspiration), necrotising enterocolitis (NEC; defined as stage $\geq 2$ of Bell's criteria), and late-onset infection (defined as bacterial or fungal infection after day 3 of life).

Data from QMH were compared with those of all neonatal centres in the VON database in a single year in 2013, the latest data available at the time of the study.

\section{Statistical analysis}

The Chi squared test was used to compare the categorical QMH data with that of VON. All P values were two-tailed, and a $\mathrm{P}$ value of $<0.05$ was considered statistically significant.

\section{Results}

\section{Study group}

A total of 449 infants with GA of $23+0$ to $29+6$ weeks and/or birth weight of $345 \mathrm{~g}$ to $1890 \mathrm{~g}$ who were born at QMH between 1 January 2005 and 31 December 2014 were included in this study. This study compared survival rate and morbidity of these infants from QMH against 38754 infants in the VON database in 2013. A significantly greater proportion of infants was delivered at 23 weeks of gestation in the VON group compared with the QMH group, which is contrary to the two groups at 27 and 29 weeks of gestation $(\mathrm{P}=0.0002)$. The proportion of infants born at 24 to 26 weeks and 28 weeks was similar for both groups (Table 1).

\section{Antenatal, maternal, and neonatal demographics}

Overall, 31.0\% of the cohort subjects at QMH were multiple births (no difference between the $\mathrm{QMH}$ and VON group; $\mathrm{P}=0.061$ ). Fewer infants in the QMH group were delivered by caesarean section compared with the VON group (58.6\% vs $68.2 \%$; $\mathrm{P}=0.0001)$. Antenatal steroids were given to $90.4 \%$ of mothers in QMH; rate of prenatal steroid use increased with increasing GA, from $73 \%$ at 23 weeks, to $82 \%-89 \%$ between 24 and 25 weeks and $90 \%-96 \%$
TABLE I. Proportions of infants born at different gestational age at Queen Mary Hospital (2005 to 20I4) and Vermont Oxford Network (2013)

\begin{tabular}{lcc}
\hline $\begin{array}{l}\text { Gestational age } \\
\text { (weeks) }\end{array}$ & \multicolumn{2}{c}{ No. (\%) of infants $^{*}$} \\
\cline { 2 - 3 } & $\begin{array}{c}\text { Queen Mary } \\
\text { Hospital (n=449) }\end{array}$ & $\begin{array}{c}\text { Vermont Oxford } \\
\text { Network (n=38754) }\end{array}$ \\
\hline 23 & $15(3.3)$ & $2523(6.5)$ \\
24 & $39(8.7)$ & $4211(10.9)$ \\
25 & $44(9.8)$ & $4501(11.6)$ \\
26 & $52(11.6)$ & $5382(13.9)$ \\
27 & $92(20.5)$ & $6336(16.3)$ \\
28 & $80(17.8)$ & $7407(19.1)$ \\
29 & $127(28.3)$ & $8394(21.7)$ \\
\hline
\end{tabular}

$\mathrm{P}=0.0002$

between 26 and 29 weeks. There was no significant difference in prenatal steroid use between the two groups $(\mathrm{P}=0.065)$. Chorioamnionitis was confirmed by placental histology in $24.3 \%$ of mothers at QMH, which was significantly more than that in the VON group (17.9\%; $\mathrm{P}=0.0006)$.

Infants at $\mathrm{QMH}$ were predominantly born to Asian (mainly Chinese) mothers whereas the majority of the VON group were of White origin $(\mathrm{P}<0.001)$. In $\mathrm{QMH}, 11.8 \%$ of the neonates were born small for GA, similar to the VON group (9.2\%, $\mathrm{P}=0.07$ ) [Table 2].

In $\mathrm{QMH}, 78 \%$ of the infants were being intubated for delivery room resuscitation. At 23 weeks, all infants underwent intubation in the delivery room. Around half of the infants delivered at 29 weeks and $20 \%$ at 28 weeks did not need intubation in the delivery room, whereas $83 \%-97 \%$ of infants born between 24 and 27 weeks needed intubation at birth. Compared with infants with GA of $\geq 26$ weeks, the proportion of infants with GA of $<26$ weeks with Apgar score of $\leq 3$ at 1 minute was higher. Only $16 \%$ of the infants were able to achieve a target core temperature of $36.5^{\circ} \mathrm{C}$ to $37.5^{\circ} \mathrm{C}$ upon admission to the neonatal intensive care unit (vs $51 \%$ in the VON group; $\mathrm{P}<0.0001)$.

\section{Survival rate on discharge and major morbidities}

In QMH, 87\% of the 449 infants survived to discharge. Rates of survival increased with increasing GA, from $27 \%$ at 23 weeks to $96 \%$ at 29 weeks. Overall survival rate of the QMH group was significantly higher than that in the VON group (87\% vs $80 \% ; \mathrm{P}=0.0006)$. In $\mathrm{QMH}$, morbidity-free survival rate increased from $0 \%$ at 23 weeks to $65 \%$ at 29 weeks (Table 3 ). Survival without major morbidity was similar when comparing the QMH and VON data (40\% vs $44 \%$; $\mathrm{P}=0.105$ ) [Table 3].

In QMH, 86\% of infants experienced RDS and 
TABLE 2. Demographic features and perinatal information of infants born at Queen Mary Hospital and Vermont Oxford Network

\begin{tabular}{|c|c|c|c|}
\hline \multirow[t]{2}{*}{ Variable } & \multicolumn{2}{|c|}{ No. (\%) of infants } & \multirow[t]{2}{*}{$P$ value } \\
\hline & $\begin{array}{l}\text { Queen Mary Hospital } \\
\qquad(n=449)\end{array}$ & $\begin{array}{l}\text { Vermont Oxford Network (No. } \\
\text { of subjects/total No.) }\end{array}$ & \\
\hline Male infant & $248(55.2)$ & 18 087/34 255 (52.8) & 0.328 \\
\hline Race or ethnic group of mother & & & $<0.001$ \\
\hline Black & $3(0.7)$ & $9165 / 33696(27.2)$ & \\
\hline White & $32(7.1)$ & 16 208/33 696 (48.1) & \\
\hline Asian & $413(92.0)$ & $1921 / 33696(5.7)$ & \\
\hline Other & $1(0.2)$ & 6402/33 $696(19.0)$ & \\
\hline Antenatal steroids to mother & $406(90.4)$ & 27 067/30 $969(87.4)$ & 0.065 \\
\hline Caesarean section & $263(58.6)$ & $23361 / 34254(68.2)$ & 0.0001 \\
\hline Multiple gestation & $139(31.0)$ & $9218 / 34269(26.9)$ & 0.061 \\
\hline SGA & $53(11.8)$ & $3150 / 34243$ (9.2) & 0.070 \\
\hline Chorioamnionitis & $109(24.3)$ & 6069/33 905 (17.9) & 0.0006 \\
\hline
\end{tabular}

Abbreviation: SGA = small for gestational age

TABLE 3. Overall survival and morbidity-free survival rates at Queen Mary Hospital and Vermont Oxford Network according to gestational age

\begin{tabular}{|c|c|c|c|c|c|c|c|c|c|c|}
\hline & \multicolumn{8}{|c|}{ Queen Mary Hospital, No. (\%) of infants } & \multirow{3}{*}{$\begin{array}{c}\begin{array}{c}\text { Vermont Oxford } \\
\text { Network }\end{array} \\
\begin{array}{c}\text { No. of subjects/ } \\
\text { total No. (\%) }\end{array}\end{array}$} & \multirow[t]{3}{*}{$P$ value } \\
\hline & \multicolumn{8}{|c|}{ Gestational age (weeks) } & & \\
\hline & $23(n=15)$ & $24(n=39)$ & $25(n=44)$ & $26(n=52)$ & $27(n=92)$ & $28(n=80)$ & $29(n=127)$ & $\begin{array}{c}\text { Total } \\
(n=449)\end{array}$ & & \\
\hline Survival & $4(27)$ & $25(64)$ & $32(73)$ & $47(90)$ & $86(93)$ & 75 (94) & $122(96)$ & $391(87)$ & 27 311/33 $927(80)$ & 0.0006 \\
\hline Morbidity-free survival & 0 & $2(5)$ & $6(14)$ & $14(27)$ & $36(39)$ & $38(48)$ & $83(65)$ & $179(40)$ & 14 793/33 775 (44) & 0.105 \\
\hline
\end{tabular}

TABLE 4. Pulmonary morbidities according to gestational age at Queen Mary Hospital and Vermont Oxford Network

\begin{tabular}{|c|c|c|c|c|c|c|c|c|c|c|}
\hline & \multicolumn{8}{|c|}{ Queen Mary Hospital, No. (\%) of infants } & \multirow{3}{*}{$\begin{array}{c}\begin{array}{c}\text { Vermont Oxford } \\
\text { Network }\end{array} \\
\begin{array}{c}\text { No. of subjects/ } \\
\text { total No. (\%) }\end{array}\end{array}$} & \multirow[t]{3}{*}{$P$ value } \\
\hline & \multicolumn{8}{|c|}{ Gestational age (weeks) } & & \\
\hline & $23(n=15)$ & $24(n=39)$ & $25(n=44)$ & $26(n=52)$ & $27(n=92)$ & $28(n=80)$ & $29(n=127)$ & $\begin{array}{c}\text { Total } \\
(n=449)\end{array}$ & & \\
\hline RDS & $14(93)$ & $39(100)$ & $43(98)$ & $49(94)$ & $85(92)$ & $70(88)$ & $88(69)$ & $388(86)$ & 27 858/32 $431(86)$ & 0.808 \\
\hline Surfactant therapy & $14(93)$ & $30(77)$ & $43(98)$ & $45(87)$ & $84(91)$ & $72(90)$ & $83(65)$ & $371(83)$ & 25 212/34 $255(74)$ & 0.0001 \\
\hline Air leaks & $3(20)$ & $4(10)$ & $2(5)$ & $3(6)$ & $4(4)$ & $3(4)$ & $2(2)$ & $21(5)$ & $1751 / 32425(5)$ & 0.570 \\
\hline CMV at any time & $15(100)$ & $38(97)$ & $43(98)$ & $50(96)$ & $86(93)$ & $71(89)$ & $88(69)$ & $391(87)$ & 23 378/32 425 (72) & 0.0001 \\
\hline Postnatal steroids & $1(7)$ & $6(15)$ & $3(7)$ & $2(4)$ & 0 & 0 & $1(1)$ & $13(3)$ & 4374/32 397 (14) & 0.0001 \\
\hline BPD & $6(40)$ & $23(59)$ & $23(52)$ & $31(60)$ & $38(41)$ & $32(40)$ & $25(20)$ & $178(40)$ & 9145/27 056 (34) & 0.011 \\
\hline Home oxygen use & 0 & $5(13)$ & $12(27)$ & $6(12)$ & $10(11)$ & $9(11)$ & $3(2)$ & $45(10)$ & $4270 / 24125(18)$ & 0.0001 \\
\hline
\end{tabular}

Abbreviations: BPD = bronchopulmonary dysplasia; CMV = continuous mechanical ventilation; RDS = respiratory distress syndrome

$83 \%$ needed surfactant therapy. Rate of mechanical both groups $(\mathrm{P}=0.57)$.

ventilation at any time decreased from $100 \%$ at 23 weeks to $69 \%$ at 29 weeks. There was no significant difference in the incidence of RDS between $\mathrm{QMH}$ and VON groups $(\mathrm{P}=0.808)$. Significantly more infants in the QMH, however, were given surfactant therapy for RDS and put on mechanical ventilation, compared with VON (83\% vs $74 \%$; $\mathrm{P}=0.0001)$. The overall frequency of pneumothorax was similar in
Use of postnatal steroids for BPD was lower in QMH compared with VON (3\% vs 14\%; P=0.0001) although the QMH rate for BPD was higher $(40 \%$ vs $34 \% ; \mathrm{P}=0.011$ ) and rate of home oxygen use was lower ( $10 \%$ vs $18 \%$; $\mathrm{P}=0.0001)$ [Table 4 ].

In $\mathrm{QMH}$, rates of early- and late-onset sepsis were $3 \%$ and $10 \%$, respectively. No significant difference was noted in the incidence of early-onset 
TABLE 5. Other neonatal morbidities according to gestational age at Queen Mary Hospital and Vermont Oxford Network

\begin{tabular}{|c|c|c|c|c|c|c|c|c|c|c|}
\hline & \multicolumn{8}{|c|}{ Queen Mary Hospital, No. (\%) of infants } & \multirow{3}{*}{$\begin{array}{c}\begin{array}{c}\text { Vermont Oxford } \\
\text { Network }\end{array} \\
\begin{array}{c}\text { No. of subjects/ } \\
\text { total No. }(\%)\end{array}\end{array}$} & \multirow[t]{3}{*}{$P$ value } \\
\hline & \multicolumn{8}{|c|}{ Gestational age (weeks) } & & \\
\hline & $23(n=15)$ & $24(n=39)$ & $25(n=44)$ & $26(n=52)$ & $27(n=92)$ & $28(n=80)$ & $29(n=127)$ & $\begin{array}{c}\text { Total } \\
(n=449)\end{array}$ & & \\
\hline \multicolumn{11}{|l|}{ Sepsis } \\
\hline Early onset & 0 & $4(10)$ & $3(7)$ & $1(2)$ & $2(2)$ & $1(1)$ & $1(1)$ & $12(3)$ & $972 / 32404(3)$ & 0.792 \\
\hline Late onset & $1(7)$ & $7(18)$ & $4(9)$ & $6(12)$ & $8(9)$ & $9(11)$ & $9(7)$ & $44(10)$ & $5012 / 30562(16)$ & 0.0002 \\
\hline NEC $\geq$ stage 2 & $1(7)$ & $4(10)$ & $3(7)$ & $1(2)$ & $6(7)$ & $3(4)$ & $6(5)$ & $24(5)$ & $1913 / 32423(6)$ & 0.693 \\
\hline PDA & $5(33)$ & $22(56)$ & $26(59)$ & $36(69)$ & $44(48)$ & $28(35)$ & $38(30)$ & $199(44)$ & 12 470/32 306 (39) & 0.015 \\
\hline $\begin{array}{l}\text { Medical treatment with } \\
\text { ibuprofen (2010-2014) }\end{array}$ & $3 / 12(25)$ & $17 / 24(71)$ & $14 / 24(58)$ & $17 / 28$ & $10 / 34(29)$ & $6 / 30(20)$ & $10 / 63(16)$ & $77 / 215(36)$ & 3793/32 422 (12) & 0.0001 \\
\hline Surgical ligation & $3(20)$ & $8(21)$ & $7(16)$ & $5(10)$ & $3(3)$ & $1(1)$ & $4(3)$ & $31(7)$ & $2270 / 32423$ (7) & 0.936 \\
\hline \multicolumn{11}{|l|}{ Grade 3/4 } \\
\hline IVH & $4(27)$ & 7 (18) & $8(18)$ & $3(6)$ & $3(3)$ & $3(4)$ & $4(3)$ & $32(7)$ & 2978/30 389 (10) & 0.070 \\
\hline PVL & $0(0)$ & $1(3)$ & $2(5)$ & $1(2)$ & $3(3)$ & $7(9)$ & $1(1)$ & $15(3)$ & $1012 / 30659(3)$ & 0.963 \\
\hline ROP $\geq$ stage 3 & $2(13)$ & $9(23)$ & $14(32)$ & $10(19)$ & $8(9)$ & $3(4)$ & $1(1)$ & $47(10)$ & $2117 / 25818(8)$ & 0.100 \\
\hline
\end{tabular}

Abbreviations: IVH = intraventricular haemorrhage; NEC = necrotising enterocolitis; PDA = patent ductus arteriosus; PVL = periventricular leukomalacia; $\mathrm{ROP}=$ retinopathy of prematurity

sepsis between $\mathrm{QMH}$ and VON $(\mathrm{P}=0.792)$ although QMH had a significantly lower rate of late-onset sepsis ( $10 \%$ vs $16 \% ; \mathrm{P}=0.0002)$ [Table 5 ].

In $\mathrm{QMH}, \mathrm{NEC}$ developed in $5 \%$ of infants ( $\geq$ stage 2) and $10 \%$ of infants were diagnosed as having severe retinopathy of prematurity ( $\geq$ stage $3)$. The overall frequencies of NEC and severe retinopathy of prematurity were similar in the QMH and VON groups $(\mathrm{P}=0.693$ and $\mathrm{P}=0.100$, respectively) [Table 5].

In $\mathrm{QMH}, \mathrm{PDA}$ was diagnosed in $44 \%$ of infants, of whom $36 \%$ were treated with ibuprofen (in 2010-2014), and 7\% with surgical closure. For management of PDA, QMH had higher rates of ibuprofen treatment than the VON group (36\% vs $12 \% ; \mathrm{P}=0.0001)$, whereas the rates of PDA ligation were similar $(\mathrm{P}=0.936)$ [Table 5].

In $\mathrm{QMH}, 7 \%$ of sonograms indicated severe IVH (grade 3 or 4); PVL was observed in 3\% of infants. There were no significant differences in the incidence of severe IVH or PVL between QMH and VON groups $(\mathrm{P}=0.070$ and $\mathrm{P}=0.963$, respectively; Table 5).

In $\mathrm{QMH}$, the length of hospital stay among survivors decreased with increasing GA, from 19 weeks at GA 23 weeks to 8 weeks at GA of 29 weeks. Similarly, PMA at discharge decreased from 42 weeks for surviving infants born at GA of 23 weeks, to 41 weeks at GA of 24 weeks, 39 to 40 weeks at GA of 25 to 27 weeks, 38 weeks at GA of 28 weeks, and 37 weeks at GA of 29 weeks.

Growth failure (body weight $<10$ th centile for age and sex) was evident in $84 \%$ of infants at QMH (vs VON 42\%; $\mathrm{P}=0.0001$ ) upon discharge.

\section{Discussion}

This study reports the mortality and morbidity in the neonatal intensive care unit in QMH over a 10-year period (2005-2014). As the only intensive care centre from China participating in the VON, QMH data provide an important source of local epidemiological information. Data recorded at QMH were compared with the entire VON database. This allows the benchmarking of our neonatal care and clinical outcomes for preterm infants internationally. Local centre-specific information about preterm infants based on GA facilitates parental counselling about high-risk infants and aids decision making.

Our study revealed that the survival rate on discharge of preterm/VLBW infants $(\leq 29+6$ weeks and/or birth weight of $<1500 \mathrm{~g}$ ) from QMH was higher than that from VON, with comparable morbidity-free survival. The higher survival rate on discharge from QMH may be partly explained by the higher proportion of 23-week GA infants in the $\mathrm{VON}$ ( $3.3 \%$ vs $6.5 \% ; \mathrm{P}=0.0002)$. Advances in perinatal and neonatal care have contributed to improved survival among preterm infants. The goal in the care of these babies should be to improve intact survival without morbidities. Among the key morbidities (severe IVH, PVL, BPD, NEC, pneumothorax, any late infection), BPD was the only clinical entity with a significantly higher incidence at QMH compared with VON (40\% vs $34 \%$; $\mathrm{P}=0.011$ ). Reducing the risk of BPD will have a great impact on morbidity-free survival in our population. ${ }^{6}$ Of note, BPD is a condition with multifactorial causes and preterm infants are predisposed to lung injury 
including ventilator-induced lung injury, infection, and inflammation. ${ }^{7-9}$ The higher rate of BPD in QMH compared with VON could be related to the higher prevalence of chorioamnionitis, a known risk factor that inhibits alveolar development. ${ }^{10}$ As we were ventilating more infants than $\mathrm{VON}$ (as evidenced by the higher rate of surfactant use for RDS and use of conventional mechanical ventilation at any time), the risk of ventilator-associated lung injury was increased. Haemodynamically significant PDA was present in a greater proportion of infants at QMH compared with VON (44\% vs 39\%; $\mathrm{P}=0.015$ ); PDA increases pulmonary blood flow and causes interstitial oedema. The mechanical ventilator setting and oxygen requirement increase as a result and provide a foundation for BPD. The risk of BPD is also influenced by growth restriction. Growth failure upon discharge was present in $84 \%$ of our infants. With poor nutrition in these infants, normal lung growth, maturation, and repair are inhibited. Postnatal steroid was used less frequently in $\mathrm{QMH}$ compared with VON (3\% vs $14 \%$ ), and may explain in part the decreased incidence of BPD in VON.

In order to reduce the incidence of BPD in our population, modifiable risk factors need to be reduced. In recent years, our unit has been managing RDS more with continuous positive airway pressure support with subsequent selective surfactant administration-that is, INSURE (INtubation, SURfactant administration, then Extubation)-in order to avoid unnecessary or prolonged ventilation, thereby reducing ventilator-associated lung injury and BPD. ${ }^{11,12}$ Targeted oxygen saturation has also been used in our centre to minimise oxygen toxicity associated with BPD. ${ }^{13,14}$

We had a significantly higher proportion of infants who were small for GA upon discharge compared with the VON group (84\% vs $42 \%$; $\mathrm{P}=0.0001$ ). Apart from affecting lung growth and maturation, postnatal growth failure is associated with poor long-term neurocognitive outcome. ${ }^{15,16}$ One possible explanation for growth failure in our population is the lack of guidelines about preterm infant nutrition (eg timing of feeding initiation and milk volume advancement, prescription of total parenteral nutrition etc). Without such guidelines, a preterm infant's caloric intake may be suboptimal with consequent compromise of growth. In order to improve the growth of our preterm infants, a standardised nutritional pathway for the VLBW infants has been in use since 2015. Its effect has yet to be evaluated.

A limitation of our study is the lack of adjustment for potential confounding factors. The two groups, $\mathrm{QMH}$ and VON, were not directly comparable, for instance, the higher survival rate of preterm infants in our centre could be partly affected by the lower proportion of GA of 23 weeks in our study population.

\section{Conclusions}

The majority of neonatal outcomes for preterm/ VLBW infants at QMH were comparable with $\mathrm{VON}$, with the exception of BPD and growth failure upon discharge. Regular auditing and benchmarking of clinical outcomes will help ensure quality improvement with implementation of new interventions and projects in our unit.

\section{Declaration}

All authors have disclosed no conflicts of interest.

\section{References}

1. Horbar JD, Plsek PE, Leahy K; NIC/Q 2000. NIC/Q 2000: establishing habits for improvement in neonatal intensive care units. Pediatrics 2003;111(4 Pt 2):e397-410.

2. Horbar JD. The Vermont-Oxford Neonatal Network: integrating research and clinical practice to improve the quality of medical care. Semin Perinatol 1995;19:124-31.

3. Annual report for infants born in 2014. Center 320. Vermont Oxford Network; 2015.

4. Fenton TR, Kim JH. A systematic review and meta-analysis to revise the Fenton growth chart for preterm infants. BMC Pediatr 2013;13:59.

5. An international classification of retinopathy of prematurity. The Committee for the Classification of Retinopathy of Prematurity. Arch Ophthalmol 1984;102:1130-4.

6. Greenough A, Ahmed N. Perinatal prevention of bronchopulmonary dysplasia. J Perinat Med 2013;41:119-26.

7. Jobe AH, Ikegami M. Mechanisms initiating lung injury in the preterm. Early Hum Dev 1998;53:81-94.

8. Kallapur SG, Jobe AH. Contribution of inflammation to lung injury and development. Arch Dis Child Fetal Neonatal Ed 2006;91:F132-5.

9. Kinsella JP, Greenough A, Abman SH. Bronchopulmonary dysplasia. Lancet 2006;367:1421-31.

10. Thomas W, Speer CP. Chorioamnionitis is essential in the evolution of bronchopulmonary dysplasia-the case in favour. Paediatr Respir Rev 2014;15:49-52.

11. Morley CJ, Davis PG, Doyle LW, et el. Nasal CPAP or intubation at birth for very preterm infants. N Engl J Med 2008;358:700-8.

12. Committee on Fetus and Newborn; American Academy of Pediatrics. Respiratory support in preterm infants at birth. Pediatrics 2014;133:171-4.

13. Supplemental Therapeutic Oxygen for Prethreshold Retinopathy of Prematurity (STOP-ROP), a randomized, controlled trial. I: primary outcomes. Pediatrics 2000;105:295-310.

14. Askie LM, Henderson-Smart DJ, Irwig L, Simpson JM. Oxygen-saturation targets and outcomes in extremely preterm infants. N Engl J Med 2003;349:959-67.

15. Ehrenkranz RA, Dusick AM, Vohr BR, Wright LL, Wrage LA, Poole WK. Growth in the neonatal intensive care unit influences neurodevelopmental and growth outcomes of extremely low birth weight infants. Pediatrics 2006;117:1253-61.

16. Franz AR, Pohlandt F, Bode $\mathrm{H}$, et al. Intrauterine, early neonatal, and postdischarge growth and neurodevelopmental outcome at 5.4 years in extremely preterm infants after intensive neonatal nutritional support. Pediatrics 2009;123:e101-9. 